\title{
A Systematic Review of Gastric Acid-Reducing Agent-Mediated Drug-Drug Interactions with Orally Administered Medications
}

\author{
Divya Patel ${ }^{1} \cdot$ Richard Bertz $^{1} \cdot$ Song Ren ${ }^{2} \cdot$ David W. Boulton $^{2} \cdot$ Mats Någård $^{2}$
}

Published online: 2 December 2019

(c) The Author(s) 2019

\begin{abstract}
Background and Objective Several review articles have been published discussing gastric acid-related drug-drug interactions (DDIs) mediated by coadministration of antacids, histamine $\mathrm{H}_{2}$ receptor antagonists, or proton pump inhibitors, but are not sufficiently comprehensive in capturing all documented DDIs with acid-reducing agents (ARAs) and tend to focus on gastric $\mathrm{pH}$-dependent DDIs and/or basic drugs. Subsequently, several new drugs have been approved, and new information is available in the literature. The objective of this systematic review is to comprehensively identify oral medications that have clinically meaningful DDIs, including loss of efficacy or adverse effects, with gastric ARAs, and categorize these medications according to mechanism of interaction.

Methods An indepth search of clinical data in the PDR3D: Reed Tech Navigator ${ }^{\text {TM }}$ for Drug Labels, University of Washington Drug-Drug Interaction Database, DailyMed, Drugs@FDA.gov, and UpToDate ${ }^{\circledR} /$ Lexicomp ${ }^{\circledR}$ Drug and Drug Interaction screening tool was conducted from 1 June to 1 August 2018. The PDR3D, University of Washington Drug-Drug Interaction Database, and DailyMed were searched with terms associated with gastric acid and ARAs. Conflicting findings were further investigated using the UpToDate ${ }^{\circledR} /$ Lexicomp ${ }^{\circledR}$ screening tool. Clinical relevance was assessed on whether an intervention was needed, and prescribing information and/or literature supporting the DDI.

Results Through the search strategy, 121 medications were found to clinically meaningfully interact with ARAs. For 38 medications the mechanism of interaction with ARAs was identified as gastric $\mathrm{pH}$ dependent, and for 83 medications the interaction was found to be not gastric $\mathrm{pH}$ mediated, with mechanisms involving metabolic enzymes, transporters, chelation, and urine alkalization. Additionally, 109 medications were studied and did not have a clinically meaningful interaction with ARAs.

Conclusion This review may provide a resource to healthcare professionals in aiding the care of patients by increasing awareness of interactions with ARAs and may also identify and potentially aid in avoiding clinically relevant DDIs and preventing risk of treatment failure and/or adverse effects. Advances in non-clinical predictions of gastric $\mathrm{pH}$-mediated DDIs may guide the need for a future clinical evaluation.
\end{abstract}

Electronic supplementary material The online version of this article (https://doi.org/10.1007/s40262-019-00844-3) contains supplementary material, which is available to authorized users.

Mats Någård

mats.nagard@astrazeneca.com

1 University of Pittsburgh School of Pharmacy, 37 S. New York Rd, Galloway, NJ 08205, USA

2 Quantitative Clinical Pharmacology, Early Clinical Development, Innovative Medicines (IMed) Biotech Unit, AstraZeneca LP, One MedImmune Way, Gaithersburg, MD 20878, USA

\section{Key Points}

This review provides an evaluation of the effectiveness and safety of currently available medicines when taken with medicines used to control stomach acid.

For medications found to have meaningful interactions, ways of avoiding or reducing the effect of the acid-controlling medication are suggested.

Medicines that are not affected by gastric-acid controllers are also identified so prescribers and patients know they do not have to be concerned about altered effectiveness or safety when using them with gastric acid controllers. 


\section{Introduction}

Gastric acid-reducing agents (ARAs) are commonly used among patients across all fields of medicine and are often recommended to treat conditions related to gastrointestinal disease [1, 2]. Because of the frequent use of ARAs, the potential for drug-drug interactions (DDIs) is an important consideration. The three ARA classes on the market include antacids, histamine $\mathrm{H}_{2}$ receptor antagonists (H2RAs), and proton pump inhibitors (PPIs). These medication classes raise gastric $\mathrm{pH}$ through different mechanisms and with different durations of action: antacids are short acting, H2RAs are intermediate acting, and PPIs are long acting [3, 4]. The H2RA and PPI classes each include agents that differ in their interaction potential via cytochrome P450 (CYP) enzymes and active transporters, which could potentially affect the metabolism and/or excretion of other concurrently administered medications [5, 6]. However, each of these classes share the potential to interact through increased gastric $\mathrm{pH}$, which may affect concurrently administered drugs with $\mathrm{pH}$ dependent solubility, $\mathrm{pH}$-dependent stability, or $\mathrm{pH}$-sensitive release from a dosage form by influencing the rate and/or extent of absorption [5].

Most ARAs are available over the counter, which can be potentially problematic in terms of DDIs, especially in patients who are taking many concurrent medications without medical supervision of their ARA use [7, 8]. Polypharmacy, generally referring to the concurrent use of five or more medications, drastically increases the risk of DDIs. To ameliorate the challenge polypharmacy poses, prescribers and pharmacists often conduct comprehensive medication reviews, including non-prescription medications, and then counsel the patient on their medications and warn them of any adverse effects or potential drug interactions and how to mitigate them [7].

A comprehensive review of gastric acid-mediated DDIs using ARAs as the perpetrator might aid in the treatment of patients with polypharmacy and potentially avoid drug interactions that would otherwise affect their care. By further identifying the specific mechanism of interaction, possible mitigation strategies and alternative options can be chosen by the prescriber. This comprehensive review could save time for prescribers and pharmacists who are responsible for the care of many patients by providing a reference to help screen for ARA-mediated DDIs. In addition, this systematic review provides mitigation strategies for ARA-mediated DDIs.

Although several review articles have been published discussing gastric acid-related DDIs mediated by coadministration of antacids [1], $\mathrm{H}_{2}$ RAs [9], or PPIs [2, 10-12], these reviews are not sufficiently comprehensive in capturing all documented DDIs with ARAs and tend to focus on gastric
pH-dependent DDIs and/or basic drugs. Subsequently, several new drugs have been approved, and new information is available in the literature. Thus, the objective of this systematic review is to comprehensively identify oral medications with clinically meaningful DDIs, including loss of efficacy or adverse effects with ARAs, and to categorize these medications according to mechanism of interaction.

\section{Factors for Drug Disposition}

ARAs may act as perpetrators (i.e., drugs that cause or are believed to have an effect on the substrate drug) with substrate medications (i.e., drugs whose systemic exposure may or may not be changed by a perpetrator drug) by affecting their absorption, metabolism, or elimination, and these mechanisms are discussed in this section.

\subsection{Absorption}

Following oral administration, medications typically are systemically absorbed through the gastrointestinal tract into the bloodstream to allow distribution to the target site(s) of action [13, 14]. The extent and rate of absorption is determined by both the properties of the medication and the gastrointestinal characteristics of the individual patient (e.g., food status, comedications, gastrointestinal disease, etc.). The intrinsic physicochemical properties of the medication are important factors for oral absorption, including stability, solubility, permeability, lipophilicity, particle size, shape and physical form of the active pharmaceutical ingredient, and formulation $[15,16]$.

To fully understand DDIs mediated by ARAs through increased gastric $\mathrm{pH}$, it is important to review physiologic gastrointestinal $\mathrm{pH}$. The range of $\mathrm{pH}$ varies widely in the human digestive tract. In the fasting state, the lower stomach secretes hydrochloric acid until it reaches a $\mathrm{pH}$ of 1.0-3.5, and a $\mathrm{pH}$ of 3.0-7 when in a fed state. The $\mathrm{pH}$ in the small intestine is $6.0-8.0$, and in the colon the $\mathrm{pH}$ is $5.5-8.0$ [14, $17,18]$.

\subsubsection{Weak Acids and Weak Bases}

When gastric $\mathrm{pH}$ is raised by ARAs, the solubility of weak acids generally increases [19]. For clinical doses of weakly acidic drugs that are not completely dissolved in gastric fluid at physiologic $\mathrm{pH}$, an increase in gastric $\mathrm{pH}$ may lead to an increased dissolution and likewise subsequent absorption rate and/or extent. For clinical doses of weakly basic drugs that are not completely dissolved at physiologic $\mathrm{pH}$, an increase in gastric $\mathrm{pH}$ would result in a decrease in dissolution and also subsequent absorption rate and/or extent [19]. 
Most clinically meaningful DDIs caused by ARAs through this mechanism are with weak bases.

\subsubsection{Formulation/Dosage Form Effect}

There are many different formulations of oral dosage forms available on the market [20]. These include immediaterelease (IR) dosage forms and modified-release (MR) dosage forms.

2.1.2.1 Modified-Release Dosage Forms MR dosage forms, often introduced to reduce dosing frequency [20], include extended-release (ER) and delayed-release (DR) forms. Examples of these ER dosage forms include controlledrelease, sustained-release, timed-release, and long-acting forms. These ER dosage forms do not commonly interact with ARAs because of a lack of involvement of a pH component in drug release.

DR dosage forms include enteric-coated products, which pass through the stomach unaltered and are then triggered to release by the higher $\mathrm{pH}$ environment of the lower gastrointestinal tract [20]. DR dosage forms protect the drug from gastric fluids, reduce gastric irritation by the drug, and improve drug absorption in the desired location of the gastrointestinal tract. Enteric coatings are beneficial particularly in regard to drugs with chemical or physical instability in acidic conditions. For those medications designed to not release in the stomach, the $\mathrm{pH}$ of release can range from 5.0 to 7.0, depending on the intended location in the gut [21]. Notably, ARAs can raise gastric $\mathrm{pH}$ above 6.0 [22], which can lead to premature release of drug formulated in a DR dosage form. The implications of this are potential degradation of the drug in gastric fluid, gastric irritation by the drug, and altered absorption rate and/or extent [23]. DR dosage forms are most likely to interact with ARAs because of the inherent $\mathrm{pH}$-related release profile. However, some DR formulations, such as time-based dosage forms, are independent of $\mathrm{pH}$.

2.1.2.2 Immediate-Release Dosage Formulations IR dosage forms dissolve rapidly after oral administration. For these formulations, the acid-base characteristics of the substrate medication are important in determining its solubility and/or its chemical stability in gastric fluid [1]. ARAs have the potential to interact with IR formulations when a substrate medication exhibits $\mathrm{pH}$-dependent solubility or $\mathrm{pH}$ dependent chemical stability.

\subsubsection{Chelation}

Polyvalent cations in antacid formulations may form an insoluble chelate complex with medications [1]. Such chelates may be poorly absorbed, reducing bioavailability of the substrate medication. Chelation requires a net cation charge of +2 or +3 ; thus, calcium-, magnesium-, and aluminumcontaining antacids are common culprits in regard to chelating effects with substrate medications. Sodium bicarbonate, the only metal ion-containing antacid with a net charge of +1 , is not subject to chelation-based DDIs [24].

\subsection{Metabolism}

\subsubsection{Cytochrome P450}

CYP is a heme-containing superfamily responsible for the biotransformation of exogenous substances, including 80\% of medications [25]. With respect to ARAs, CYP1A2, CYP2C9, CYP2C19, CYP2D6, and CYP3A4 are the most important from a DDI standpoint. CYP1A2 is predominantly expressed in the liver and is responsible for the metabolism of medications such as clozapine, olanzapine, theophylline, and derivatives thereof $[25,26]$. Among the CYP2 enzymes, CYP2C9 is the most abundantly expressed CYP2 enzyme in the liver, accounting for the metabolism of $20 \%$ of medications [26]. Because of the polymorphic potential of CYP2C9, variation in the metabolism and disposition of drugs is evident between individuals, which can be problematic for those drugs with a narrow therapeutic index [25, 26]. CYP2C19 is a clinically important enzyme that metabolizes several drugs, including omeprazole, diazepam, and propranolol [25-27]. Many clinically relevant interactions of ARAs with CYPmetabolized drugs occur via CYP2C19 [25]. The enzyme CYP2D6 is responsible for the metabolism of $\sim 20 \%$ of medications [25, 26]. CYP3A4 is one of the major CYP3A enzymes in humans, which are involved in the metabolism of a wide range of substrate types and are, in fact, responsible for the metabolism of $\sim 30$ to $50 \%$ of medications $[25,26]$.

H2RAs and PPIs have the potential to act either as inhibitors or inducers of CYP enzymes [5]. When acting as an inhibitor of CYP, concomitant administration of an ARA may result in increased systemic exposure of a drug or decreased conversion of a prodrug to its active form. In fact, inhibition of CYP represents a common cause of DDIs seen in clinical practice [28]. Such inhibition of CYPs by H2RAs and PPIs occurs via reversible competitive inhibition, where the substrate medication and ARA (or inhibitor) both bind to the active site of the enzyme. The degree of inhibition depends on the concentration of the ARA at the active site, and the 'CYP profiles' of both the substrate medication and ARA [2].

In contrast to CYP inhibition, induction of CYP enzymes may occur, resulting in either increased activity of a prodrug or heightened elimination of the drug itself. Inducible enzymes include CYP2A, CYP2B, CYP2C, CYP2E, and CYP3A [29]. Notably, ARA-mediated CYP induction is less commonly seen with respect to clinically meaningful DDIs. 


\subsection{Elimination}

\subsubsection{Organic Cation Transporter 2}

Organic cation transporters (OCTs) are expressed throughout the body; however, OCT2 is primarily localized in the proximal tubule of the kidney. OCTs work in tandem with efflux transporters to aid in drug excretion [6]. For example, OCTs function to secrete endogenous cations and remove positively charged drugs (e.g., ranitidine) from the body. On the basis of in vitro data, OCT2 can be inhibited by H2RAs, which may lead to decreased renal excretion of substrate medication and increased systemic exposure and potential toxicity [6].

\subsubsection{P-Glycoprotein}

P-Glycoprotein (P-gp), also known as multidrug resistance protein 1 , is important for drug transport, aiding in the movement of the medication from the intestinal mucosa back into the gut lumen, thus contributing to first-pass elimination [30]. Intuitively, inhibition of this transporter would mean a medication would be absorbed to a higher degree, potentially leading to adverse effects possibly associated with attainment of toxic plasma concentrations of medications even when given at recommended doses.

\subsubsection{Urine Alkalization}

Antacids have the potential to increase urinary $\mathrm{pH}$ [1]. In a study of healthy men, increases in urine $\mathrm{pH}$ of 0.48 and $0.86 \mathrm{U}$ were observed with administration of magnesium hydroxide and aluminum and magnesium hydroxide suspension, respectively, over a 7-day period [31]. Urinary $\mathrm{pH}$ can be a major factor for the renal excretion of medications. In alkaline urine, the renal clearance of weakly acidic drug molecules will tend to be increased. In an alkaline environment, weakly acidic drugs are polar (charged), and thus are less likely to pass through membranes for reabsorption into the systemic circulation, and weakly basic drugs will be rendered neutral and remain non-polar (uncharged), allowing them to be more likely to pass through membranes to re-enter the systemic circulation and increase their systemic exposure [32]. Increased urinary $\mathrm{pH}$ may lead to either toxic concentrations being reached for weakly basic drug molecules or reduced efficacy for weakly acidic drug molecules.

\subsection{Implications}

Therapeutic doses of ARAs can raise the gastric $\mathrm{pH}$ to $>6.0$ [19]. It is important to differentiate the mechanism by which different ARAs work and the degree to which they affect gastric $\mathrm{pH}$. In addition, it is important to identify other possible mechanisms of interaction between ARAs and substrate medications. By understanding such mechanisms, possible mitigation strategies can be investigated. Currently, common mitigation strategies include spacing of the dosing interval, avoidance of interaction, choosing an alternative agent, or monitoring of therapy $[1,2,9]$.

\section{Types of Gastric Acid-Reducing Agents and their Mechanisms of Interaction}

\subsection{Antacids}

Antacids consist of basic substances coupled with a cation [1]. Antacids directly neutralize gastric acid, providing a quick onset of action and a short duration of acid suppression of $\sim 2 \mathrm{~h}$ due to gastric emptying and gastric acid secretion. The most commonly available over-the-counter antacids are sodium bicarbonate, calcium carbonate, aluminum hydroxide, and magnesium hydroxide (Table 1). The possible mechanisms underlying DDIs for antacids are discussed in Sects. 3.1.1-3.1.4.

\subsubsection{Gastric pH Elevation}

Neutralization of gastric fluid by antacids may alter the dissolution, absorption, stability, or release of dosage forms of substrate medications [1]. However, the short duration of gastric $\mathrm{pH}$ elevation by antacids allows for the potential mitigation strategy of separation of doses apart in time of the antacid and substrate medication.

\subsubsection{Chelation}

Sodium bicarbonate is the only antacid containing a metal ion that is not known to chelate with substrate medications (Sect. 2.1.3) [24]. Accordingly, sodium bicarbonate can be used as an alternative antacid therapy over therapies containing magnesium and/or aluminum, metal ions that chelate with substrate medications. Again, separation of doses in time is a possible mitigation strategy to avoid chelationbased drug interactions. In addition, it is possible to switch to an H2RA or PPI to avoid such interactions, obviously as long as there is no new potential interaction.

\subsubsection{Gastrointestinal Motility}

Magnesium-containing antacids may promote gastric emptying and accelerate the rate of absorption of some drugs 


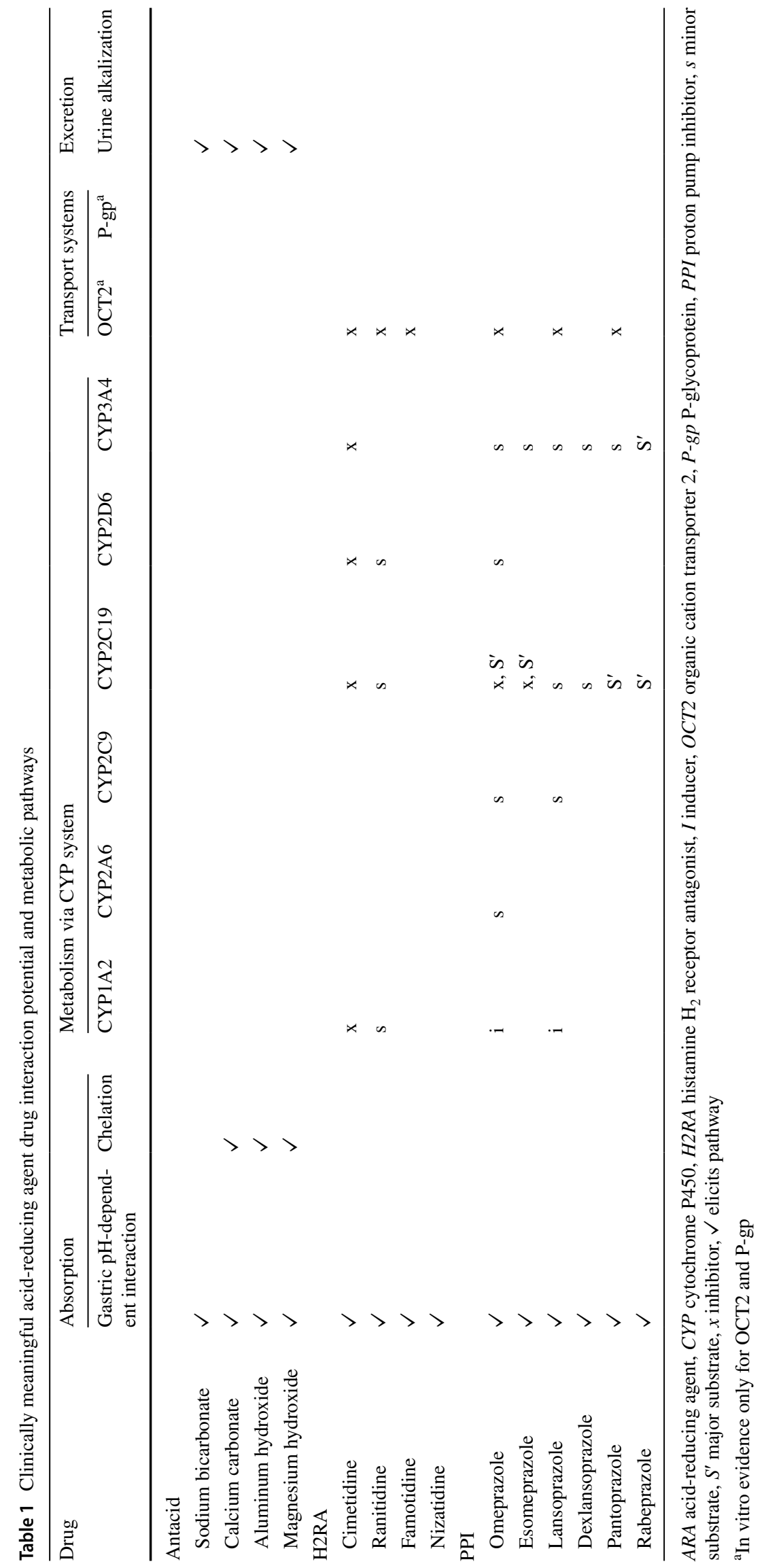


[1]. The clinical relevance of this is unclear. Notably, formulations containing magnesium alone are no longer used as antacids essentially because of the adverse effect of diarrhea. Combination products containing both magnesium and aluminum are now more common; aluminum counteracts the increase in gastric emptying observed with magnesium alone.

\subsubsection{Alkalization of Urine}

Since antacids are basic compounds, they have the potential to alkalize urine, altering the renal excretion of weakly acidic and weakly basic medications [32]. Possible mitigation strategies proposed in the prescribing information include selection of an alternative ARA (H2RA or PPI), monitoring for increased or decreased effects of substrate medication, and possible dose adjustment of the substrate medication. In this case, separation of dosing in time is less likely to be a successful mitigation strategy; however, this has not been well-studied.

\subsection{Histamine $\mathrm{H}_{2}$ Receptor Antagonists}

Commonly used H2RAs available over the counter include cimetidine, ranitidine, nizatidine, and famotidine [9, 33, 34]. $\mathrm{H} 2 \mathrm{RAs}$ compete reversibly with histamine at $\mathrm{H}_{2}$ receptors in gastric parietal cells to reduce gastric acid secretion. Potential for DDIs with H2RAs should be considered in the context of their pharmacokinetic profile, which drives the effect on gastric $\mathrm{pH}$, with a peak effect at $2 \mathrm{~h}$ and a duration of action of up to $12 \mathrm{~h}$ [35]. The possible mechanisms underlying putative DDIs with H2RAs are discussed in Sects. 3.2.1-3.2.3

\subsubsection{Gastric pH Elevation}

Various mitigation strategies have been proposed, including avoidance of the H2RA, administering the substrate at least $2 \mathrm{~h}$ before the H2RA, dosing the substrate and H2RA simultaneously, and administering the substrate medication 10-12 $\mathrm{h}$ after the H2RA [19, 35]. When considering these mitigation strategies, thought must be given to the pharmacokinetics of the substrate medication and extent of the effect of increased gastric $\mathrm{pH}$ on the substrate medication.

\subsubsection{The Cytochrome P450 Enzyme System}

H2RAs have the potential to interact with substrate medications that undergo CYP enzyme metabolism [5]. H2RAs can inhibit CYP enzymes, including CYP1A2, CYP2C9,
CYP2C19, CYP2D6, and CYP3A4. Cimetidine, the first approved H2RA, is an inhibitor of multiple CYP enzymes; however, newer H2RAs have less effect on CYP metabolism. For example, ranitidine is not as potent of a CYP inhibitor as cimetidine, and famotidine has a negligible effect on CYP enzymes [5].

Possible mitigation strategies when a clinically meaningful CYP-based interaction is seen with H2RAs include avoidance, monitoring for increased or decreased effects and possible dose adjustment of the substrate medication, or selection of an alternative ARA or substrate medication.

\subsubsection{Organic Cation Transporter 2}

H2RAs have the potential to inhibit OCT2, which is the most clinically relevant of the OCTs for H2RA-mediated DDIs [6]. Possible mitigation strategies when a clinically meaningful OCT2-based interaction is seen with H2RAs include avoidance, monitoring for increased or decreased effects and possible dose adjustment of the substrate medication, or selection of alternative ARA or substrate medication.

\subsection{Proton Pump Inhibitors}

Common PPIs include omeprazole, esomeprazole, lansoprazole, dexlansoprazole, pantoprazole, and rabeprazole, with many of these being available without a prescription [2, 10-12, 36-38]. PPIs irreversibly bind and inactivate the proton pump (i.e., the hydrogen/potassium adenosine triphosphatase system) at the secretory surface of gastric parietal cells. This results in suppression of gastric acid production for $>24 \mathrm{~h}$, but 4 days of repeated dosing is required to reach maximal effect. Similar efficacy has been shown in acid suppression studies comparing omeprazole, lansoprazole, rabeprazole, and pantoprazole [4]. Esomeprazole has a stronger degree of acid suppression, with a longer period of intragastric $\mathrm{pH}>4$. However, the gastric $\mathrm{pH}$-dependent interaction is class specific and does not appear to be markedly different among individual PPIs $[4,36]$. The multiple possible DDI mechanisms of PPIs are discussed in Sects. 3.3.1-3.3.3.

\subsubsection{Gastric pH Elevation}

In contrast to other ARAs, the duration of raised gastric $\mathrm{pH}$ is sustained over the dose interval for PPIs. Therefore, there are fewer options for mitigation strategies for PPIs compared with antacids and H2RAs. The possible mitigation strategies for gastric $\mathrm{pH}$ elevation caused by PPIs include avoidance of the PPI, monitoring for increased or decreased effects of substrate medication, and setting a maximum dose of the PPI. 


\subsubsection{The Cytochrome P450 Enzyme System}

PPIs can affect CYP2C19 and CYP1A2 activity [2, 11, $12,38]$. Omeprazole and esomeprazole reversibly inhibit CYP2C19 to a clinically meaningful degree, whereas other marketed PPIs inhibit CYP2C19 but not to a degree that is clinically relevant [39-41]. Omeprazole has been shown to clinically induce the activity of CYP1A2 in some studies but not others [2]. Possible mitigation strategies for CYPmediated drug interactions with PPIs include avoidance of the PPI, monitoring for increased or decreased effect with possible dose reduction of substrate medication, or immediate dose reduction of substrate medication upon initiation of the PPI. While separation of dosing in time is sometimes an option for PPIs when a gastric $\mathrm{pH}-$ dependent mechanism is suspected, it is not recommended for CYP-only-based interactions.

\subsubsection{P-Glycoprotein Efflux Transporter}

It is unknown if clinically meaningful DDIs with PPIs are mediated through P-gp. One in vitro study concluded that omeprazole, lansoprazole, and pantoprazole are substrates and inhibitors of P-gp, but with only moderate potency [38].

\section{Comprehensive Review of Gastric Acid-Reducing Agent-Mediated Drug- Drug Interactions}

\subsection{Methods}

This review is a Preferred Reporting Items for Systematic Reviews and Meta-Analyses (PRISMA) 2009-guided systematic review to identify oral medications that were substrates of an interaction with ARAs/perpetrators [42]. To conduct these analyses, four commercially available databases were used.

The initial search strategy was completed using the PDR3D: Reed Tech Navigator ${ }^{\mathrm{TM}}$ for Drug Labels, which is a database of prescribing information from a broad range of countries/regions. The 30 terms in Table 2 include generic names of antacids, H2RAs, and PPIs, as well as three common brands of combination antacid products. The first 27 terms listed in Table 2 were each searched in the "clinical pharmacology" and "drug interaction" sections of the prescribing information available through the database using the "OR" function. The last three terms in Table 2 related to dosage forms searched in "all" sections of the prescribing information. The PDR3D database was searched during the period of 1 June 2018-1 August 2018.

The University of Washington Drug-Drug Interaction Database (DIDB) was also searched from 15 June 2018 to
Table 2 PDR3D: Reed Tech Navigator ${ }^{\mathrm{TM}}$ and DailyMed search terms

\begin{tabular}{ll}
\hline PPI & Gastric acid \\
Proton pump inhibitor & Gastric $\mathrm{pH}$ \\
Omeprazole & $\mathrm{pH}$ dependent \\
Esomeprazole & Chelation \\
Lansoprazole & Antacids \\
Dexlansoprazole & Sodium bicarbonate \\
Pantoprazole & Calcium carbonate \\
Rabeprazole & Aluminum hydroxide \\
H2 antagonists & Magnesium hydroxide $^{\text {H2 blockers }}$ \\
Cimetidine & Maalox $^{\mathrm{a}}$ \\
Ranitidine & Riopan $^{\mathrm{b}}$ \\
Famotidine & Gaviscon $^{\mathrm{c}}$ \\
Nizatidine & Enteric coated \\
Acid-reducing & Delayed release \\
\hline
\end{tabular}

PPI proton pump inhibitor

${ }^{\mathrm{a}}$ Maalox ${ }^{\circledR}$. Aluminum hydroxide $225 \mathrm{mg}$, magnesium hydroxide $200 \mathrm{mg}$

${ }^{\mathrm{b}}$ Riopan ${ }^{\circledR}$. Magaldrate oral suspension

${ }^{\mathrm{c}}$ Gaviscon ${ }^{\circledR}$. Aluminum hydroxide and magnesium carbonate suspension

26 July 2018. The DIDB has the largest manually curated collection of in vitro and in vivo data related to drug interactions in humans primarily based on scientific literature. A query was created for the term "precipitant," which by the University of Washington database definition is the equivalent of a perpetrator. Each term in Table 3 was searched individually as a "precipitant" and specified for "in vivo" results only. Medications under all categories were evaluated for interactions, as follows: the query "in vivo no mechanism" aided in identifying substrates that do not interact with ARAs or do not have an interaction that is clinically

Table 3 University of Washington Drug-Drug Interaction database search terms

\begin{tabular}{ll}
\hline Omeprazole & Nizatidine \\
Esomeprazole & Sodium bicarbonate \\
Lansoprazole & Calcium carbonate \\
Dexlansoprazole & Aluminum hydroxide \\
Pantoprazole & Magnesium hydroxide $^{\text {Rabeprazole }}$ \\
Cimetidine & Maalox $^{\mathrm{a}}$ \\
Ranitidine & Riopan $^{\mathrm{b}}$ \\
Famotidine & Gaviscon $^{\mathrm{c}}$ \\
\hline
\end{tabular}

${ }^{\mathrm{a}}$ Maalox ${ }^{\circledR}$. Aluminum hydroxide $225 \mathrm{mg}$, magnesium hydroxide $200 \mathrm{mg}$

${ }^{\mathrm{b}}$ Riopan ${ }^{\circledR}$. Magaldrate oral suspension

${ }^{\mathrm{c}}$ Gaviscon ${ }^{\circledR}$. Aluminum hydroxide and magnesium carbonate suspension 
meaningful, the query "in vivo other mechanism $>20 \%$ " aided in identifying substrates reported to have a gastric $\mathrm{pH}$-based interaction with ARAs, the queries "in vivo no inhibition" and "in vivo no induction" covered any medications considered to be gastric $\mathrm{pH}$ based but not included in the "in vivo other mechanism $>20 \%$ " group, and the queries "in vivo induction $>20 \%$ " and "in vivo inhibition $>20 \%$ " covered medications that interacted via metabolic enzymes and transporters. Citations were provided to the prescribing information for the medication available at the Drugs@ FDA webpage and/or PubMed publications evaluating the interaction.

Pharmaceutical companies with approved medications for marketing in the USA are required to have up-to-date prescribing information available to the public, and the DailyMed database contains this information. The search strategy used for PDR3D (see earlier in this section) was replicated for the DailyMed database from 28 June 2018 to 1 August 2018 (Table 2).

The information collected from each database was organized on the basis of the presence or absence of a clinically meaningful interaction. For medications exhibiting an interaction, the substrate drug name, ARA (perpetrator), clinical effect on substrate drug, mechanism of interaction, evidence of interaction (clinical data), and intervention strategy were complied. For medications without an interaction, the medication name, concurrent ARA name, directions of use, and clinical data supporting the lack of a clinically meaningful interaction were also compiled.

Throughout the search strategy described earlier, repeat medications, names of ARA products (omeprazole, ranitidine, Maalox ${ }^{\circledR}$, etc.), non-oral dosage forms, and medications with no basis for a pharmacokinetic interaction were removed. The remaining medications were then evaluated to determine whether the drug was a substrate or a perpetrator, and perpetrators were removed. Potential substrates were subsequently evaluated for a clinically meaningful interaction or no interaction/no clinically meaningful interaction. A clinically meaningful interaction was defined as when the prescribing information recommended some intervention for either the perpetrator or substrate as a result of the interaction (e.g., spacing, avoidance, or change in dose). If a pharmacokinetic interaction was observed, but no action was recommended by the prescribing information, this was considered to be a non-clinically meaningful interaction. Substrates with clinically meaningful interactions were further evaluated for description of the mechanism(s) of interaction, which were typically claimed in the prescribing information; however, for the few medications that did not claim a probable mechanism in the label, PubMed was used to try to determine the mechanism. The greatest emphasis was placed on the prescribing information, while case reports were not considered a definitive source for an associated interaction. If there was conflicting evidence presented between databases, the UpToDate ${ }^{\circledR} /$ Lexicomp ${ }^{\circledR}$ Drug and Drug Interaction screening tool was used to resolve this.

The UpToDate ${ }^{\circledR} /$ Lexicomp $^{\circledR}$ screening tool uses scientific literature and prescribing information to provide peerreviewed clinical practice advice to healthcare professionals when different databases present conflicting evidence for the presence or absence of a clinically meaningful interaction for a particular medication pair. Conflicting evidence appeared $\sim 10 \%$ of the time, mostly for interactions considered to be non-gastric $\mathrm{pH}$ based. This was resolved by using a decision-making sequence. First, the prescribing information was referenced for evidence of an interaction; if there was no evidence for a clinically meaningful interaction and scientific literature (PubMed) presented conflicting evidence for a potential interaction, the UpToDate ${ }^{\circledR} / \mathrm{Lexi}^{-}$ comp ${ }^{\circledR}$ screening tool was used to evaluate current clinical practice along with any supporting information. In addition, this tool was used to cross-reference the interactions identified through PDR3D, the University of Washington DIDB, and/or DailyMed. This screening tool was used from 28 June 2018 to 1 August 2018.

\subsection{Results}

Figure 1 describes the PRISMA-compliant flow diagram of the search strategy conducted and the output that was further analyzed. 'Identification' used PDR3D, University of Washington DIDB, and DailyMed to compile a list of medications to be screened for an interaction with ARAs. 'Screening' allowed for the removal of repeat medications, names of ARA products, non-oral dosage forms, and medications not relevant to an interaction with ARAs. 'Eligibility' allowed for identification of medications to be potential substrates or perpetrators, with perpetrators being removed. Potential substrates were then analyzed for the presence or absence of a clinically meaningful interaction. Substrates with a clinically meaningful interaction were distinguished on the basis of their mechanism of interaction (gastric $\mathrm{pH}$ based or non-gastric $\mathrm{pH}$ based).

Medications with a gastric $\mathrm{pH}$-dependent mechanism of interaction with ARAs deemed to be clinically significant are shown in Table 4. Table 1 in the Electronic Supplementary Material expands on each interaction, provides clinical data and references, and comments further on mitigation strategies.

Table 5 lists medications that interact with ARAs based on a non-gastric $\mathrm{pH}$-based mechanism, including chelation, CYP-mediated interactions, transporter-mediated 


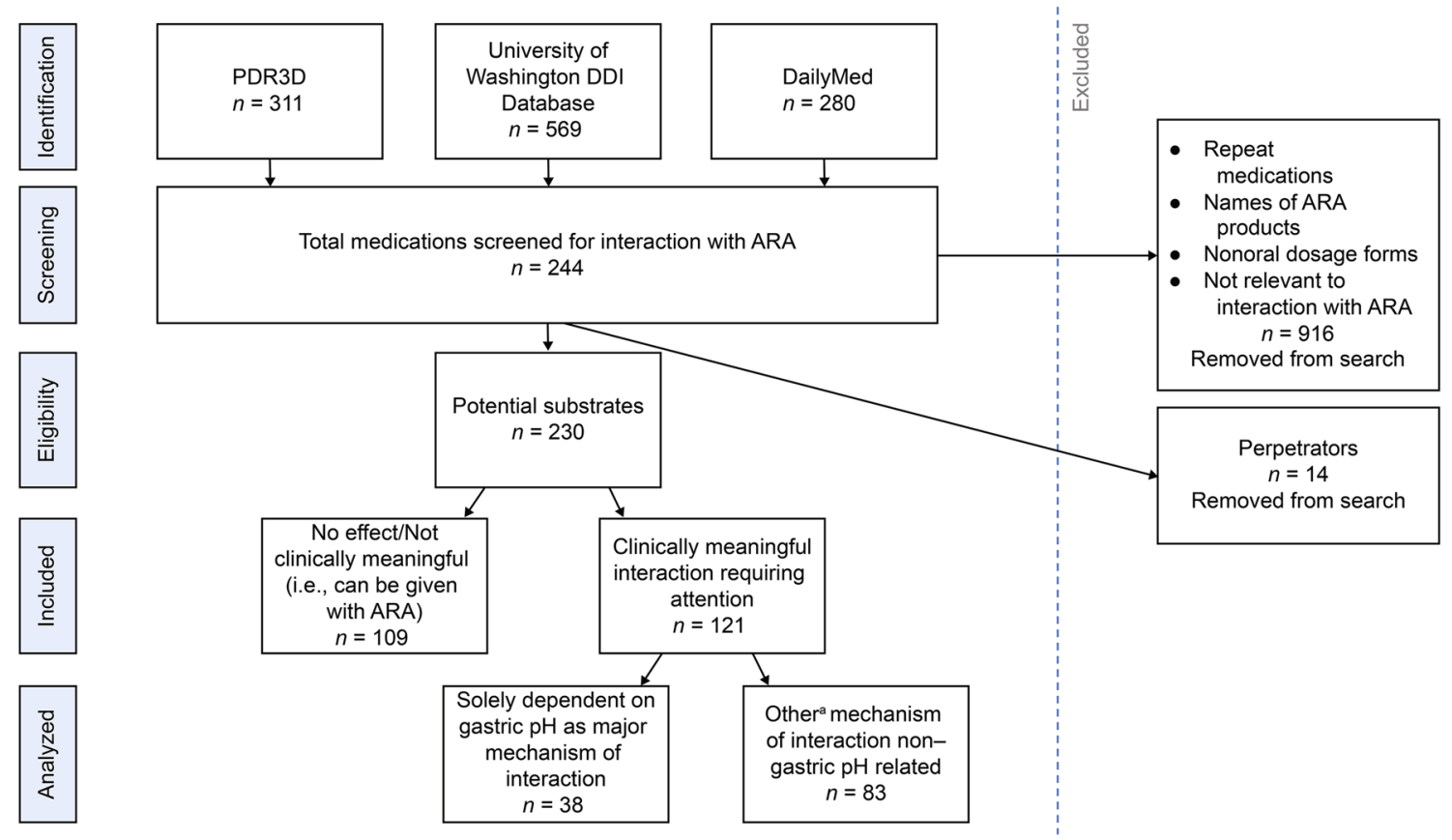

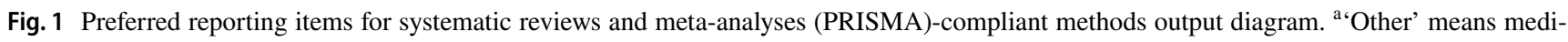
ated by CYP, transporter, chelation, urine alkalization, etc. ARA acid-reducing agent, $D D I$ drug-drug interaction

interactions, and urine alkalization. Table 2 in the Electronic Supplementary Material provides indepth information on the mechanism of interaction, clinical data, mitigation strategies, and references.

Table 6 shows medications with no clinically meaningful interaction with ARAs. Table 3 in the Electronic Supplementary Material provides supportive clinical data and references for these medications to support their use with ARAs without therapy change. All medications shown in Table 6 (and Table 3 in the Electronic Supplementary Material) have clinical data supporting lack of a clinically meaningful interaction with a designated ARA agent. Dependent on study design, it can reasonably be concluded that most of these mediations do not exhibit any gastric $\mathrm{pH}$-dependent interaction.

\section{Potential Strategies to Mitigate Gastric Acid-Reducing Drug-Drug Interactions}

Figure 2 provides a decision-making sequence that prescribers and pharmacists can use to navigate through an interaction posed with an ARA. When an interaction is identified, the prescriber or pharmacist can choose to either change the
ARA product or change the substrate medication. For example, changes would include either spacing of dosing in time, changing the dose, or selecting an alternative agent. When choosing to change the ARA, options include using a mitigation strategy or referring to Table 1 to select an alternative ARA. Table 1 shows the interaction profile of each ARA, and so selection of a non-interacting ARA would be made. When choosing to change the substrate medication, options include selecting an agent from a specific table depending on the mechanism of interaction. Strategies for both are shown for each mechanism of interaction.

\section{Discussion}

Current resources available permit identification of medications that may interact with ARAs; however, reference to multiple sources is required for a comprehensive examination, which becomes challenging in clinical practice. A single resource of DDIs with ARAs may support prescribers and pharmacists in avoiding or mitigating adverse drug combinations in patients undergoing ARA treatment. In this 
Table 4 Substrates with a clinically meaningful gastric $\mathrm{pH}$-dependent mechanism of interaction $(n=38)$

\begin{tabular}{|c|c|c|c|}
\hline Drug & Antacid & H2RA & PPI \\
\hline Acalabrutinib & Separate by $2 \mathrm{~h}$ & Take $2 \mathrm{~h}$ before $\mathrm{H} 2 \mathrm{RA}$ & $x$ \\
\hline Atazanavir & $\begin{array}{l}\text { Take } 2 \mathrm{~h} \text { before or } 1 \mathrm{~h} \text { after } \\
\text { antacid }\end{array}$ & $\begin{array}{l}\text { HIV treatment-naïve patients: take } \\
2 \mathrm{~h} \text { before or } 10 \mathrm{~h} \text { after H2RA in } \\
\text { those unable to tolerate ritona- } \\
\text { vir; patients receiving ritonavir } \\
\text { should take H2RA simultane- } \\
\text { ously with atazanavir and food } \\
\text { or atazanavir } 10 \mathrm{~h} \text { after H2RA } \\
\text { HIV treatment-experienced } \\
\text { patients: take H2RA simultane- } \\
\text { ously with atazanavir and food } \\
\text { or atazanavir } 10 \mathrm{~h} \text { after H2RA }\end{array}$ & $\begin{array}{l}\times \\
\text { Can be administered with boosted } \\
\text { atazanavir } 12 \mathrm{~h} \text { after PPI in } \\
\text { patients that are treatment-naïve } \\
\text { to atazanavir }\end{array}$ \\
\hline Bisacodyl DR & Separate by at least $1 \mathrm{~h}$ & - & - \\
\hline $\begin{array}{l}\text { Bismuth subcitrate potassium, } \\
\text { metronidazole, tetracycline } \\
\text { hydrochloride }\end{array}$ & $x$ & $\begin{array}{l}\times \text { with cimetidine and other } \\
\text { inhibitors of CYP }\end{array}$ & $\checkmark$ \\
\hline Bosutinib & Separate by minimum of $2 \mathrm{~h}$ & Separate by minimum of $2 \mathrm{~h}$ & $x$ \\
\hline Cefditoren pivoxil & $x$ & $\times$ & $x$ \\
\hline Cefpodoxime proxetil & Separate by $2 \mathrm{~h}$ & Separate by minimum of $2 \mathrm{~h}$ & Monitor \\
\hline Cefuroxime axetil & $\begin{array}{l}\text { Take } 1 \mathrm{~h} \text { before or } 2 \mathrm{~h} \text { after } \\
\text { antacid }\end{array}$ & $x$ & $x$ \\
\hline Dabigatran etexilate mesylate & $\begin{array}{l}\text { Canada: take } 2 \mathrm{~h} \text { before antacid; } \\
\text { monitor }\end{array}$ & USA: $\checkmark$ & USA: $\checkmark$ \\
\hline Dasatinib & Separate by minimum of $2 \mathrm{~h}$ & $x$ & $x$ \\
\hline Delaviradine & Separate by $1 \mathrm{~h}$ & $x$ & $x$ \\
\hline Digoxin & Monitor & - & Monitor \\
\hline $\begin{array}{l}\text { Emtricitabine, rilpivirine hydro- } \\
\text { chloride, tenofovir disoproxil } \\
\left.\text { fumarate (Complera }{ }^{\circledR}\right)\end{array}$ & $\begin{array}{l}\text { Take } 4 \mathrm{~h} \text { before or } 2 \mathrm{~h} \text { after } \\
\text { antacid }\end{array}$ & $\begin{array}{l}\text { Take } 4 \mathrm{~h} \text { before or } 12 \mathrm{~h} \text { after } \\
\text { H2RA }\end{array}$ & $x$ \\
\hline Erlotinib & Separate by a few hours & $\begin{array}{l}\text { Take } 2 \mathrm{~h} \text { before or } 10 \mathrm{~h} \text { after } \\
\text { H2RA }\end{array}$ & $x$ \\
\hline Ferrous sulfate & $\begin{array}{l}\text { Separate as much as possible, } \\
\text { monitor }\end{array}$ & - & - \\
\hline Gefitinib & Separate by $6 \mathrm{~h}$ & Separate by $6 \mathrm{~h}$ & $\begin{array}{l}\times \\
\text { If necessary, separate by } 12 \mathrm{~h}\end{array}$ \\
\hline Hyoscyamine & $\begin{array}{l}\text { Administer before meals and } \\
\text { antacid after meals }\end{array}$ & - & - \\
\hline Indinavir & - & Monitor & Monitor \\
\hline Itraconazole & $\begin{array}{l}\text { Separate by } 2 \mathrm{~h} \text {; consider adminis- } \\
\text { tering with non-diet cola }\end{array}$ & $\begin{array}{l}\text { Separate by } 2 \mathrm{~h} \text {; monitor; admin- } \\
\text { ister with non-diet cola }\end{array}$ & $\begin{array}{l}\text { Separate by } 2 \mathrm{~h} \text {; monitor; adminis- } \\
\text { ter with non-diet cola }\end{array}$ \\
\hline Ketoconazole & $\begin{array}{l}\text { Take } 2 \mathrm{~h} \text { before or } 1 \mathrm{~h} \text { after ant- } \\
\text { acid; monitor }\end{array}$ & $\begin{array}{l}\text { Monitor; administer with non-diet } \\
\text { cola }\end{array}$ & $\begin{array}{l}\text { Monitor; administer with non-diet } \\
\text { cola }\end{array}$ \\
\hline Lapatinib & USA: $\checkmark$ UK: $\times$ & USA: $\checkmark$ UK: $\times$ & USA: $\checkmark$ UK: $\times$ \\
\hline Ledipasvir, sofosbuvir (Harvoni ${ }^{\circledR}$ ) & Separate by $4 \mathrm{~h}$ & Time simultaneously or $12 \mathrm{~h}$ apart & $\begin{array}{l}\text { Simultaneously under fasting condi- } \\
\text { tions }\end{array}$ \\
\hline Mefenamic acid & $x$ & - & - \\
\hline Mesalamine & $x$ & - & - \\
\hline Nelfinavir & - & Monitor & $x$ \\
\hline Neratinib & Take $3 \mathrm{~h}$ after antacid & $\begin{array}{l}\text { Take } 2 \mathrm{~h} \text { before or } 10 \mathrm{~h} \text { after } \\
\text { H2RA }\end{array}$ & $x$ \\
\hline Nilotinib & Separate by $2 \mathrm{~h}$ & $\begin{array}{l}\text { Take } 2 \mathrm{~h} \text { before or } 10 \mathrm{~h} \text { after } \\
\text { H2RA }\end{array}$ & $x$ \\
\hline Pazopanib & $x$ & $x$ & $x$ \\
\hline Phenytoin & Do not take at same time of day & - & - \\
\hline
\end{tabular}


Table 4 (continued)

\begin{tabular}{|c|c|c|c|}
\hline Drug & Antacid & H2RA & PPI \\
\hline $\begin{array}{l}\text { Posaconazole oral suspension } \\
\left(\text { Noxafil }^{\circledR}\right)\end{array}$ & $\checkmark$ & $\begin{array}{l}\checkmark \text { for H2RA other than cimeti- } \\
\text { dine; } \times \text { for cimetidine }\end{array}$ & $\times$ \\
\hline Raltegravir (Isentress ${ }^{\circledR}$ ) & $\begin{array}{l}\times \text { for aluminum and/or magne- } \\
\text { sium antacids; } \times \text { for calcium car- } \\
\text { bonate for high-dose raltegravir; } \\
\checkmark \text { for raltegravir }\end{array}$ & - & $\checkmark$ \\
\hline Riociguat & Separate by $1 \mathrm{~h}$ & - & $\checkmark$ \\
\hline Risedronate sodium (Atelvia DR) & $\times$ & $\times$ & $\times$ \\
\hline $\begin{array}{l}\text { Sofosbuvir, velpatasvir } \\
\left.\text { (Epclusa }^{\circledR}\right)\end{array}$ & Separate by $4 \mathrm{~h}$ & Time simultaneously or $12 \mathrm{~h}$ apart & $\begin{array}{l}\times \\
\text { If necessary, take with food and } 4 \mathrm{~h} \\
\text { before PPI }\end{array}$ \\
\hline
\end{tabular}

Medications were identified via searches and screens of the PDR3D: Reed Tech Navigator ${ }^{\mathrm{TM}}$, University of Washington Drug-Drug Interaction Database (DIDB), and DailyMed databases as detailed in Sect. 4.1

CYP cytochrome $\mathrm{P} 450, D R$ delayed release, $H 2 R A$ histamine $\mathrm{H}_{2}$ receptor antagonist, PPI proton pump inhibitor, $\checkmark$ coadministration shows no interaction, $\times$ coadministration not recommended, - no information available

comprehensive review, 121 individual medications were found to clinically meaningfully interact with ARAs. Thirtyeight medications were identified to have a mechanism of interaction that was gastric $\mathrm{pH}$ dependent, and 83 medications were found to interact with ARAs with a non-gastric $\mathrm{pH}$-mediated interaction (CYP/transporter/chelation/urine alkalization).

This review identified the mechanisms underlying DDIs, which allowed for the proposal of mitigation strategies. While mitigation strategies for introducing an ARA (perpetrator) and a substrate medication together are described in this review, it is also important to re-evaluate therapy changes when ARA (perpetrator) doses are decreased or stopped. For some medications, mitigation strategies recommended in prescribing information when H2RAs are perpetrators of a clinically meaningful gastric $\mathrm{pH}$-dependent interaction are often inconsistent and sometimes debatable based on their pharmacodynamic properties. H2RA activity can persist for up to $12 \mathrm{~h}$, with peak acid suppression occurring around $2 \mathrm{~h}$. The prescribing information of some medications, such as bosutinib, indicates separation by $2 \mathrm{~h}$ before or after the H2RA. Although administering a substrate medication $2 \mathrm{~h}$ before an H2RA is appropriate, administering the substrate medication $2 \mathrm{~h}$ after the H2RA can be problematic because this is the time of the peak gastric acid raising effect. Waiting 10-12 h after an H2RA has been administered would strongly suggest mitigation of a gastric $\mathrm{pH}$-dependent interaction based on the minimal pharmacodynamic effects of H2RAs at this time.

Specifically for chelation-based interactions, clinical data for substrate medications were often extrapolated to include other agents in the class or derivatives of the substrate medication. Although the clinical study may not have used the exact substrate medication and ARA combination, health authorities or manufacturers believed that alternative agents in the same class or substrate medication derivatives have potential for similar DDIs. For example, a common class of anti-infective medications are fluoroquinolones. Most antacids are known to chelate with fluoroquinolones; not all fluoroquinolones have been studied with antacids, but data for ciprofloxacin have been applied to other agents in the class, such as trovafloxacin, because of the similar chemistry prone to chelation among these agents.

Because gastric $\mathrm{pH}$ elevation is a characteristic shared among all three classes of ARAs, if no clinically meaningful gastric $\mathrm{pH}$-mediated interaction is observed with one ARA, it is highly unlikely that no gastric pH-mediated interaction will be observed with any ARA. Similarly, if a clinically meaningful gastric $\mathrm{pH}$-mediated interaction is observed with one ARA, it is highly likely that a gastric pH-mediated interaction will be observed with all ARAs. This allows for extrapolation of findings to different ARAs based on gastric $\mathrm{pH}$ alone. Because of individual characteristics of ARAs (antacids, H2RAs, PPIs), non-gastric pH-and chelation-based interactions, such as CYP, transporter, and urine alkalization, cannot be extrapolated between ARAs.

Interestingly, 109 medications were found to not have any clinically meaningful interaction with ARAs, suggesting that clinical DDI studies may have been conducted unnecessarily. It may be possible to identify drugs likely or not likely to have ARA-mediated drug interactions from their physicochemical characteristics, which would reduce the need for clinical gastric $\mathrm{pH}$-mediated DDI studies. This also indicates the potential utility of a health authority 
Table 5 Medications with a clinically meaningful other mechanism of interaction, not gastric pH-based $(n=83)$

\begin{tabular}{|c|c|c|}
\hline Victim drug & ARA/perpetrator & Mechanism of interaction \\
\hline \multicolumn{3}{|l|}{ Anti-infectives } \\
\hline Azithromycin & Magnesium-/aluminum-containing antacids & Likely chelation \\
\hline Bictegravir & Antacids & Likely chelation \\
\hline Chloroquine & Cimetidine & Inhibition of CYP \\
\hline Ciprofloxacin & Magnesium-/aluminum-containing antacids & Chelation \\
\hline Dolutegravir & Calcium-based antacids & Chelation \\
\hline Doxycycline & $\begin{array}{l}\text { Magnesium-/aluminum-/calcium-containing antacids, } \\
\text { PPIs }\end{array}$ & Likely chelation \\
\hline Gemifloxacin & Magnesium-/aluminum-containing antacids & Chelation \\
\hline Levofloxacin & Magnesium-/aluminum-containing antacids & Chelation \\
\hline Methenamine & Antacids & Urine alkalization \\
\hline Minocycline & Magnesium-/aluminum-/calcium-containing antacids & Likely chelation \\
\hline Moxifloxacin & Magnesium-/aluminum-containing antacids & Chelation \\
\hline Norfloxacin & Cation-containing antacids ${ }^{\mathrm{a}}$ & Chelation \\
\hline Quinine sulfate & Antacids/H2RAs & Chelation/inhibition of CYP3A4 \\
\hline Tetracycline & Magnesium-/aluminum-/calcium-containing antacids & Likely chelation \\
\hline \multicolumn{3}{|l|}{ CNS agents } \\
\hline Alprazolam & Cimetidine & Inhibition of CYP3A4 \\
\hline Carbamazepine & Cimetidine & Likely inhibition of CYP3A4 \\
\hline Citalopram & Cimetidine/omeprazole & Likely inhibition of CYP/inhibition of CYP2C19 \\
\hline Clobazam & Omeprazole & Inhibition of CYP2C19 \\
\hline Clozapine & Cimetidine & Inhibition of CYP3A4 \\
\hline Dalfampridine & Cimetidine & Inhibition of OCT2 \\
\hline Desipramine & Cimetidine & Likely inhibition of CYP \\
\hline Doxepin & Cimetidine & Likely inhibition of CYP \\
\hline Escitalopram & Cimetidine/proton pump inhibitors & Likely inhibition of CYP/inhibition of CYP2C19 \\
\hline Gabapentin & Antacid containing aluminum and magnesium & Possible chelation \\
\hline Lisdexamfetamine & Sodium bicarbonate & Urine alkalization \\
\hline Memantine & Antacids (sodium bicarbonate) & Urine alkalization \\
\hline Mirtazapine & Cimetidine & Likely inhibition of CYP \\
\hline Paroxetine & Cimetidine & Likely inhibition of CYP \\
\hline Pramipexole & Cimetidine & Inhibition of OCT2 \\
\hline Sulpiride & Antacids & Unknown \\
\hline Tizanidine & Cimetidine & Inhibition of CYP1A2 \\
\hline Zolmitriptan & Cimetidine & Likely inhibition of CYP \\
\hline \multicolumn{3}{|l|}{ Cardiovascular agents } \\
\hline Captopril & Antacids & Unknown \\
\hline Carvedilol & Cimetidine & Likely inhibition of CYP \\
\hline Diltiazem & Cimetidine & Likely inhibition of CYP3A4 \\
\hline Dofetilide & Cimetidine & Inhibition of renal tubular secretion \\
\hline Felodipine & Cimetidine & Inhibition of CYP3A4 \\
\hline Fosinopril & Antacids & Unknown \\
\hline Nifedipine & Cimetidine & Inhibition of CYP \\
\hline Nimodipine & Cimetidine & Inhibition of CYP3A4 \\
\hline Nisoldipine & Cimetidine & Likely inhibition of CYP3A4 \\
\hline Nitrendipine & Cimetidine & Likely inhibition of CYP \\
\hline Pindolol & Cimetidine & $\begin{array}{l}\text { Likely inhibition of CYP or inhibition of renal clear- } \\
\text { ance }\end{array}$ \\
\hline Procainamide & Cimetidine & Likely inhibition of renal tubular secretion \\
\hline Propafenone & Cimetidine & Likely inhibition of CYP \\
\hline
\end{tabular}


Table 5 (continued)

\begin{tabular}{|c|c|c|}
\hline Victim drug & ARA/perpetrator & Mechanism of interaction \\
\hline Quinidine & Cimetidine & Likely inhibition of CYP3A4 \\
\hline Rosuvastatin & Antacids & Possible chelation \\
\hline Sotalol & Aluminum- and/or magnesium-containing antacids & Likely chelation \\
\hline Verapamil & Cimetidine & Likely inhibition of CYP3A4 \\
\hline \multicolumn{3}{|l|}{ Immune suppressant agents } \\
\hline Cyclosporine & H2RAs & Unknown \\
\hline Mycophenolate mofetil & Antacids with magnesium and/or aluminum hydroxide & Chelation \\
\hline Mycophenolic acid & Antacids with magnesium and/or aluminum hydroxide & Chelation \\
\hline Tacrolimus & Proton pump inhibitors & Likely inhibition of CYP3A4 \\
\hline \multicolumn{3}{|l|}{ Blood-modifying agents } \\
\hline Acenocoumarol & Cimetidine & Inhibition of CYP \\
\hline Cilostazol & Omeprazole & Inhibition of CYP2C19 \\
\hline Clopidogrel & Proton pump inhibitors (esomeprazole, omeprazole) & Inhibition of CYP2C19 \\
\hline Eltrombopag & Cation-containing antacids ${ }^{\mathrm{a}}$ & Chelation \\
\hline Warfarin & Cimetidine & Inhibition of hydroxylation in the liver \\
\hline \multicolumn{3}{|l|}{ Metal chelators } \\
\hline Deferasirox & Aluminum-containing antacids & Chelation \\
\hline Deferiprone & Antacids & Chelation \\
\hline Trientine & Antacids & Metal binding/chelation \\
\hline \multicolumn{3}{|l|}{ Anti-diabetic agents } \\
\hline Glimepiride & H2RAs (cimetidine, famotidine, nizatidine, ranitidine) & Inhibition of metabolism and/or renal transport \\
\hline Glipizide & H2RAs (cimetidine, famotidine, nizatidine, ranitidine) & Inhibition of metabolism and/or renal transport \\
\hline Metformin & Cimetidine & Likely inhibition of OCT2 \\
\hline Tolbutamide & Cimetidine & Inhibition of metabolism and/or renal transport \\
\hline \multicolumn{3}{|l|}{ Bisphosphonate } \\
\hline Alendronate & Antacids & Likely chelation \\
\hline \multicolumn{3}{|l|}{ Antirheumatic } \\
\hline Penicillamine & Antacids & Likely chelation \\
\hline \multicolumn{3}{|l|}{ Chemotherapy } \\
\hline 5-Fluorouracil & Cimetidine & $\begin{array}{l}\text { Likely a combination of inhibition of metabolism and } \\
\text { decreased liver blood flow }\end{array}$ \\
\hline \multicolumn{3}{|l|}{ Exchange resin } \\
\hline Sodium polystyrene sulfonate & Antacids & Likely chelation \\
\hline \multicolumn{3}{|l|}{ Gastrointestinal agents } \\
\hline Alosetron & Cimetidine & Inhibition of CYP1A2 \\
\hline \multicolumn{3}{|l|}{ Respiratory agents } \\
\hline Roflumilast & Cimetidine & Inhibition of CYP3A4 \\
\hline \multicolumn{3}{|l|}{ Urinary agents } \\
\hline Tamsulosin & Cimetidine & Inhibition of CYP3A4 \\
\hline Lanthanum carbonate & Antacids & Unclear, possible chelation \\
\hline \multicolumn{3}{|l|}{ Cholinergic agonist } \\
\hline Varenicline & H2RAs (cimetidine, famotidine, nizatidine, ranitidine) & Possible inhibition of OCT2 \\
\hline
\end{tabular}

Medications were identified via searches and screens of the PDR3D: Reed Tech Navigator ${ }^{\mathrm{TM}}$, University of Washington Drug-Drug Interaction Database (DIDB), and DailyMed databases as detailed in Sect. 4.1

$A R A$ acid-reducing agent, $C N S$ central nervous system, CYP cytochrome $\mathrm{P} 450, H 2 R A$ histamine $\mathrm{H}_{2}$ receptor antagonist, $O C T 2$ organic cation transporter 2

at is suspected that 'cation-containing antacids' refer to polyvalent cations and not sodium bicarbonate when the mechanism of interaction is chelation 
Table 6 Medications with no clinically meaningful interaction with one or more acid-reducing agents $(n=109)$

\begin{tabular}{|c|c|c|c|}
\hline Acitretin & Donepezil & Lisdexamfetamine & Sertindole \\
\hline Alectinib & Dronedarone & Lopinavir and ritonavir $\left(\right.$ Kaletra $\left.^{\circledR}\right)$ & Sildenafil \\
\hline Ambrisentan & Duloxetine & Losartan & Sodium oxybate \\
\hline Amlodipine & Efavirenz & Meloxicam & Sorafenib \\
\hline Aripiprazole & Elbasvir and grazoprevir (Zepatier ${ }^{\circledR}$ ) & Metronidazole & Sulfasalazine \\
\hline Asenapine & Eliglustat & Moexipril & Sulindac \\
\hline Aspirin & Eprosartan & Naproxen DR & Tapentadol \\
\hline $\begin{array}{l}\text { Aspirin/extended-release dipyrida- } \\
\text { mole }\left(\text { Aggrenox }{ }^{\circledR}\right)\end{array}$ & Etravirine & Nebivolol & Telithromycin \\
\hline Axitinib & Ezetimibe & Nevirapine & Temozolomide \\
\hline Azacitidine & Famciclovir & Nifedipine & Topotecan \\
\hline Betrixaban & Febuxostat & Nintedanib & Tramadol \\
\hline Boceprevir & Fenofibric acid & Obeticholic acid & Trandolapril \\
\hline Bortezomib & Fenoprofen & Osimertinib & Ulipristal acetate \\
\hline Brexpiprazole & Fluconazole & Oxcarbazepine & Valacyclovir \\
\hline Cabozantinib & Fluvastatin & Palbociclib & Valproic acid \\
\hline Carvedilol & Fosamprenavir & Paricalcitol & Valsartan \\
\hline Cephalexin & Gabapentin & Pioglitazone & Vandetanib \\
\hline Ceritinib & Gabapentin enacarbil & Piroxicam & Venlafaxine \\
\hline Cobimetinib & Garenoxacin & Ponatinib & Vilazodone \\
\hline Crizotinib & Glecaprevir/pibrentasvir (Mavyret ${ }^{\mathrm{TM}}$ ) & Posaconazole delayed release capsules & Vismodegib \\
\hline Dabigatran etexilate mesylate & Glimepiride & Prasugrel & Vorapaxar \\
\hline Danoprevir & Imatinib & Propranolol & Voriconazole \\
\hline Dapsone & Indinavir & Raloxifene & Zolpidem \\
\hline Darunavir & Isavuconazonium sulfate & Ramelteon & \\
\hline Diazepam & Isoniazid & Repaglinide & \\
\hline Diclofenac & Itraconazole oral suspension & Risperidone & \\
\hline Digoxin & Lamotrigine & Rivaroxaban & \\
\hline Divalproex & Letrozole & Saxagliptin & \\
\hline
\end{tabular}

Medications were identified via searches and screens of the PDR3D: Reed Tech Navigator ${ }^{\mathrm{TM}}$, University of Washington Drug-Drug Interaction Database (DIDB), and DailyMed databases as detailed in Sect. 4.1

$D R$ delayed release

guidance on this topic describing when a clinical study is, or is not, necessary.

Limitations of this review are that the search strategy was not replicated by a second individual, the risk for incomplete retrieval of interactions via the search strategy used, and that any additional information available after 1 August 2018 was not captured. The search strategy did not specifically include the names of the potassium-competitive acid pump antagonists revaprazan [43] and vonoprazan fumarate [44], which are approved in South Korea and Japan, respectively. Additionally, these drugs were not identified using the broad search terms, likely due to the limited number of countries in which they are approved.

\section{Conclusions}

This comprehensive review of DDIs using ARAs as a perpetrator will potentially aid in the treatment of patients receiving polypharmacy, permit avoidance of DDIs that would otherwise affect patient care, and save time for prescribers and pharmacists. Additionally, an effort was made to capture various mitigation strategies that were recommended by different health authorities (e.g., those in Canada and the European Union) to better apply this review outside of the USA. 


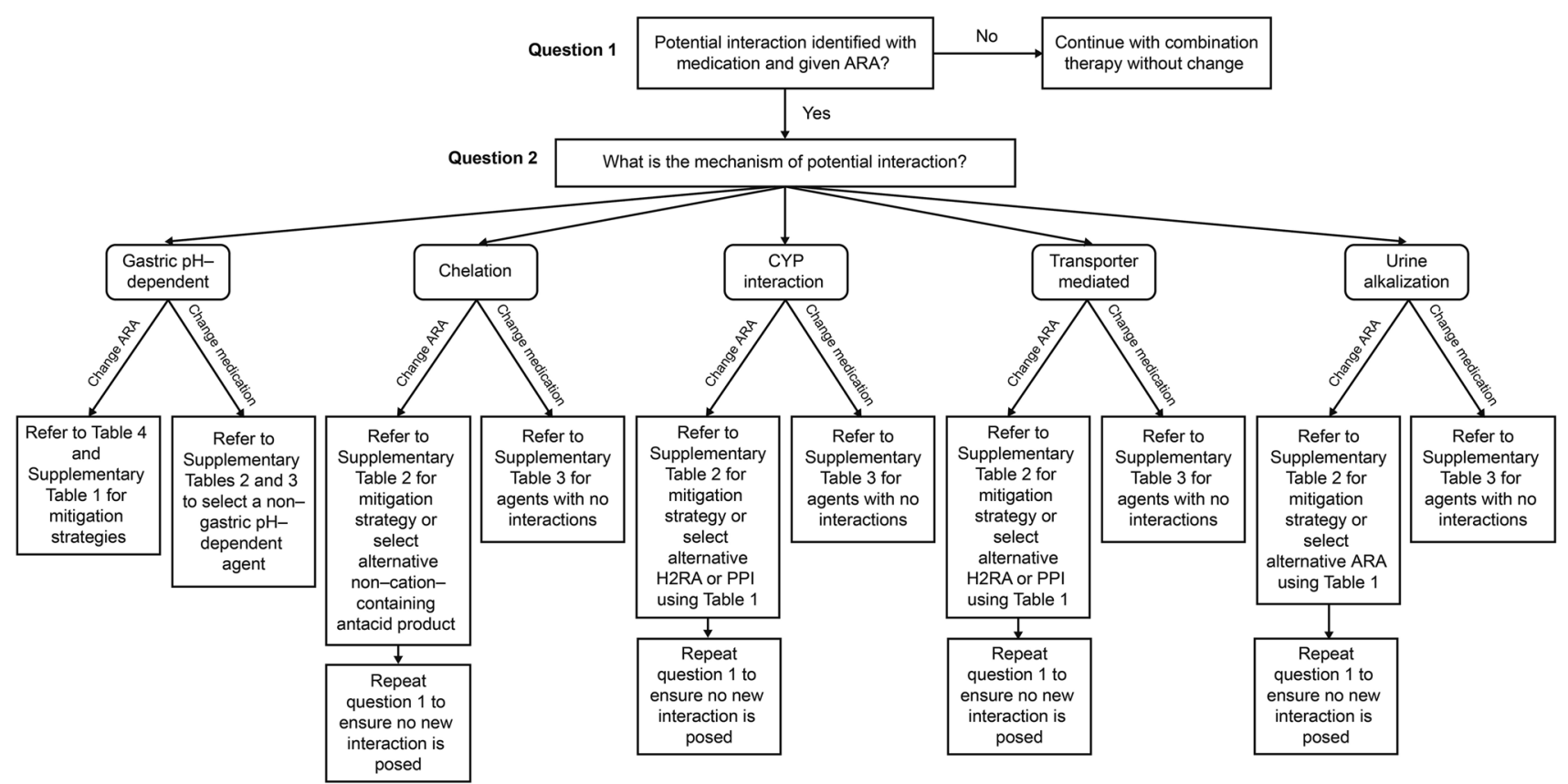

Fig. 2 Decision-making tree for selecting a mitigation strategy. $A R A$ acid-reducing agent, $C Y P$ cytochrome $\mathrm{P} 450, H 2 R A$ histamine $\mathrm{H}_{2}$ receptor antagonist, PPI proton pump inhibitor

Acknowledgements The authors would like to acknowledge Deborah Anzalone, Kathryn DeStefano, Scott Tutak, Carol Moreno Quinn, Ian Sabir, Karin Mueller, Scott Adler, Mary Whealy, and Mary Beth DeYoung for their input and guidance. inScience Communications, Springer Healthcare (Philadelphia, PA, USA) provided editorial support funded by AstraZeneca.

Author Contributions All authors made substantial contributions to the analysis and interpretation of study data; wrote various drafts of the manuscript; and provided their final approval of the version to be published. All authors gave their agreement to be accountable for all aspects of the work.

\section{Compliance with Ethical Standards}

Funding Divya Patel completed a summer internship that was funded by AstraZeneca. inScience Communications, Springer Healthcare (Philadelphia, PA, USA) provided editorial support funded by AstraZeneca.

Conflicts of interest Divya Patel completed a summer internship funded by AstraZeneca. Mats Någård, Song Ren, and David Boulton are full-time employees and shareholders of AstraZeneca. Richard Bertz has no relevant conflicts of interest.

Open Access This article is distributed under the terms of the Creative Commons Attribution-NonCommercial 4.0 International License (http://creativecommons.org/licenses/by-nc/4.0/), which permits any noncommercial use, distribution, and reproduction in any medium, provided you give appropriate credit to the original author(s) and the source, provide a link to the Creative Commons license, and indicate if changes were made.

\section{References}

1. Ogawa R, Echizen H. Clinically significant drug interactions with antacids: an update. Drugs. 2011;71(14):1839-64.

2. Ogawa R, Echizen H. Drug-drug interaction profiles of proton pump inhibitors. Clin Pharmacokinet. 2010;49(8):509-33.

3. Feldman M. Comparison of the effects of over-the-counter famotidine and calcium carbonate antacid on postprandial gastric acid. A randomized controlled trial. JAMA. 1996;275(18):1428-31.

4. Shin JM, Sachs G. Pharmacology of proton pump inhibitors. Curr Gastroenterol Rep. 2008;10(6):528-34.

5. Humphries TJ, Merritt GJ. Review article: drug interactions with agents used to treat acid-related diseases. Aliment Pharmacol Ther. 1999;13(s3):18-26.

6. Giacomini KM, Huang SM, Tweedie DJ, Benet LZ, Brouwer KL, Chu X, et al. Membrane transporters in drug development. Nat Rev Drug Discov. 2010;9(3):215-36.

7. Hajjar ER, Cafiero AC, Hanlon JT. Polypharmacy in elderly patients. Am J Geriatr Pharmacother. 2007;5(4):345-51.

8. Trifirò G, Corrao S, Alacqua M, Moretti S, Tari M, Caputi AP, et al. Interaction risk with proton pump inhibitors in general practice: significant disagreement between different drug-related information sources. Br J Clin Pharmacol. 2006;62(5):582-90.

9. Sax MJ. Clinically important adverse effects and drug interactions with $\mathrm{H}_{2}$-receptor antagonists: an update. Pharmacotherapy. 1987;7(6 Pt 2):110S-5S.

10. Johnson DA, Katz PO, Armstrong D, Cohen H, Delaney BC, Howden CW, et al. The safety of appropriate use of over-thecounter proton pump inhibitors: an evidence-based review and Delphi consensus. Drugs. 2017;77(5):547-61.

11. Mossner J. The indications, applications, and risks of proton pump inhibitors. Dtsch Arztebl Int. 2016;113(27-28):477-83.

12. Wedemeyer R-S, Blume H. Pharmacokinetic drug interaction profiles of proton pump inhibitors: an update. Drug Saf. 2014;37(4):201-11. 
13. Kostewicz ES, Aarons L, Bergstrand M, Bolger MB, Galetin A, Hatley $\mathrm{O}$, et al. PBPK models for the prediction of in vivo performance of oral dosage forms. Eur J Pharm Sci. 2014;57:300-21.

14. Sjögren E, Abrahamsson B, Augustijns P, Becker D, Bolger MB, Brewster $\mathrm{M}$, et al. In vivo methods for drug absorption-comparative physiologies, model selection, correlations with in vitro methods (IVIVC), and applications for formulation/API/excipient characterization including food effects. Eur J Pharm Sci. 2014;57:99-151.

15. Bergström CAS, Holm R, Jørgensen SA, Andersson SBE, Artursson $\mathrm{P}$, Beato $\mathrm{S}$, et al. Early pharmaceutical profiling to predict oral drug absorption: current status and unmet needs. Eur J Pharm Sci. 2014;57:173-99.

16. Lahner E, Annibale B, Delle Fave G. Systematic review: impaired drug absorption related to the co-administration of antisecretory therapy. Aliment Pharmacol Ther. 2009;29(12):1219-29.

17. Fallingborg $\mathrm{J}$. Intraluminal $\mathrm{pH}$ of the human gastrointestinal tract. Dan Med Bull. 1999;46(3):183-96.

18. Evans DF, Pye G, Bramley R, Clark AG, Dyson TJ, Hardcastle JD. Measurement of gastrointestinal $\mathrm{pH}$ profiles in normal ambulant human subjects. Gut. 1988;29(8):1035-41.

19. Zhang L, Wu F, Lee SC, Zhao H. pH-dependent drug-drug interactions for weak base drugs: potential implications for new drug development. Clin Pharmacol Ther. 2014;96(2):266-77.

20. Allen LV, Jr., Popovich NG, Ansel HC. Ansel's pharmaceutical dosage forms and drug delivery systems, ninth edition. J Pharm Technol. 2010;26(3):167-8.

21. Yoshida T, Lai TC, Kwon GS, Sako K. pH- and ion-sensitive polymers for drug delivery. Expert Opin Drug Deliv. 2013;10(11):1497-513.

22. Bendtsen F, Ovesen L, Rosenkilde-Gram B, Rune SJ. Effect of omeprazole on intragastric and duodenal bulb acidity in duodenal ulcer patients. Aliment Pharmacol Ther. 1989;3(2):151-8.

23. Abuhelwa AY, Williams DB, Upton RN, Foster DJ. Food, gastrointestinal $\mathrm{pH}$, and models of oral drug absorption. Eur J Pharm Biopharm. 2017;112:234-48.

24. Maton PN, Burton ME. Antacids revisited: a review of their clinical pharmacology and recommended therapeutic use. Drugs. 1999;57(6):855-70.

25. Zanger UM, Schwab M. Cytochrome P450 enzymes in drug metabolism: regulation of gene expression, enzyme activities, and impact of genetic variation. Pharmacol Ther. 2013;138(1):103-41.

26. Lee S-J, Shin J-G. The pharmacogenomics of cytochrome P450s: from molecular to clinical application. In: Yamazaki H, editor. Fifty years of cytochrome P450 research. Tokyo: Springer Japan; 2014. p. $345-70$

27. Inderal (propranolol hydrochloride) [prescribing information]. Philadelphia: Wyeth Pharmaceuticals Inc., a subsidiary of Pfizer Inc.; 2017.

28. Lin JH, Lu AY. Inhibition and induction of cytochrome P450 and the clinical implications. Clin Pharmacokinet. 1998;35(5):361-90.

29. Kleinschmidt KC, Delaney KA. In: Hoffman RS, Howland MA, Lewin NA, Nelson LS, Goldfrank LR, editors. Goldfrank's toxicologic emergencies. 10th ed. New York: McGraw-Hill; 2015. p. $155-67$.

30. Trevor AJ, Katzung BG, Kruidering-Hall M. Katzung and Trevor's pharmacology: examination and board review. 11th ed. New York: McGraw-Hill; 2015. p. 35-40.

31. Gibaldi M, Grundhofer B, Levy G. Effect of antacids on $\mathrm{pH}$ of urine. Clin Pharmacol Ther. 1974;16(3):520-5.

32. Prescott LF. Mechanisms of renal excretion of drugs (with special reference to drugs used by anaesthetists). Br J Anaesth. 1972;44(3):246-51.

33. Bourdet DL. Differential substrate and inhibitory activities of ranitidine and famotidine toward human organic cation transporter 1 (hOCT1; SLC22A1), hOCT2 (SLC22A2), and hOCT3 (SLC22A3). J Pharmacol Exp Ther. 2005;315(3):1288-97.

34. Echizen H, Ishizaki T. Clinical pharmacokinetics of famotidine. Clin Pharmacokinet. 1991;21(3):178-94.

35. Nugent CC, Terrell JM. H2 blockers. StatPearls. Treasure Island: StatPearls Publishing; 2019.

36. Hatlebakk JG. Review article: gastric acidity—comparison of esomeprazole with other proton pump inhibitors. Aliment Pharmacol Ther. 2003;17(suppl 1):10-5.

37. Hitzl M, Klein K, Zanger UM, Fritz P, Nüssler AK, Neuhaus $\mathrm{P}$, et al. Influence of omeprazole on multidrug resistance protein 3 expression in human liver. J Pharmacol Exp Ther. 2003;304(2):524-30.

38. Pauli-Magnus C, Rekersbrink S, Klotz U, Fromm MF. Interaction of omeprazole, lansoprazole and pantoprazole with P-glycoprotein. Naunyn Schmiedebergs Arch Pharmacol. 2001;364(6):551-7.

39. Kuzin M, Schoretsanitis G, Haen E, Stegmann B, Hiemke C, Grunder G, et al. Effects of the proton pump inhibitors omeprazole and pantoprazole on the cytochrome P450-mediated metabolism of venlafaxine. Clin Pharmacokinet. 2018;57(6):729-37.

40. Unge $P$, Andersson T. Drug interactions with proton pump inhibitors. Drug Saf. 1997;16(3):171-9.

41. Li XQ, Andersson TB, Ahlstrom M, Weidolf L. Comparison of inhibitory effects of the proton pump-inhibiting drugs omeprazole, esomeprazole, lansoprazole, pantoprazole, and rabeprazole on human cytochrome P450 activities. Drug Metab Dispos. 2004;32(8):821-7.

42. Moher D, Liberati A, Tetzlaff J, Altman DG. Preferred reporting items for systematic reviews and meta-analyses: the PRISMA statement. PLoS Med. 2009;6(7):e1000097.

43. Lee JS, Cho JY, Song H, Kim EH, Hahm KB. Revaprazan, a novel acid pump antagonist, exerts anti-inflammatory action against Helicobacter pylori-induced COX-2 expression by inactivating Akt signaling. J Clin Biochem Nutr. 2012;51(2):77-83.

44. Yang X, Li Y, Sun Y, Zhang M, Guo C, Mirza IA, et al. Vonoprazan: a novel and potent alternative in the treatment of acidrelated diseases. Dig Dis Sci. 2018;63(2):302-11. 